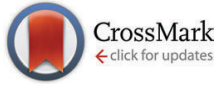

Cite this: Chem. Commun., 2015, 51,477

Received 10th October 2014, Accepted 24th October 2014

DOI: $10.1039 / \mathrm{c} 4 \mathrm{cc} 08032 \mathrm{~g}$

www.rsc.org/chemcomm

\section{Mesomeric betaine - N-heterocyclic carbene interconversions of 1,2,4-triazolium-phenolates. Sulfur, selenium, and borane adduct formation $\dagger$}

\author{
Ming Liu, ${ }^{a}$ Martin Nieger ${ }^{\mathrm{b}}$ and Andreas Schmidt*a
}

The conjugated mesomeric betaines 2-(1-phenyl-4H-1,2,4-triazolium4-yl)phenolates are masked N-heterocyclic carbenes of 1,2,4-triazole which can be trapped as thiones and selenones. Reaction with triethylborane and triphenylborane resulted in the formation of first representatives of a new zwitterionic heterocyclic ring system, benzo[e]1,2,4-triazolo[3,4-c][1,4,2]oxazaborinium-4-ide, as a formal trapping product of an anionic $\mathrm{N}$-heterocyclic carbene.

Recently, mesomeric betaines (MB) have come into the focus of $\mathrm{N}$-heterocyclic carbene (NHC) research as it was recognized that mesomeric betaines not only comprise versatile starting materials for the preparation of a broad variety of NHCs, but also stimulate the designs of new architectures and variations in their charge properties. The chemical and physical properties of mesomeric betaines are strongly dependent on their types of conjugation which define five distinct classes of mesomeric betaines. Two of them were not recognized until 2013. ${ }^{1}$ As summarized in the first review articles, ${ }^{2}$ the types of conjugation of mesomeric betaines also determine their transformations into $\mathrm{N}$-heterocyclic carbenes. Thus, some pseudo-cross-conjugated mesomeric betaines (PCCMB) are widely applied as stable precursors of normal N-heterocyclic carbenes (nNHC). ${ }^{3}$ Scheme 1 shows the PCCMB imidazolium-2-carboxylate 1, which gives 2 upon decarboxylation. ${ }^{4}$ Other suitable PCCMBs for the generation of nNHCs are pyrazolium-3-carboxylates, ${ }^{5}$ indazolium-3-carboxylates ${ }^{6}$ and pyridinium-2-carboxylates. ${ }^{7} \mathrm{~N}$-heterocyclic carbenes as well as anions derived thereof can also be generated from conjugated mesomeric betaines (CMB), as exemplified by 3-7. Thus, nitron $3^{8}$ and imidazolium-4-aminide $4^{9}$ are in tautomeric equilibrium with their corresponding NHCs. The anionic N-heterocyclic

\footnotetext{
${ }^{a}$ Clausthal University of Technology, Institute of Organic Chemistry, Leibnizstrasse 6, D-38678 Clausthal-Zellerfeld, Germany. E-mail: schmidt@ioc.tu-clausthal.de

${ }^{b}$ Laboratory of Inorganic Chemistry, Department of Chemistry, University of Helsinki, P.O. Box 55 (A.I. Virtasen aukio 1), FIN-00014 Helsinki, Finland

$\dagger$ Electronic supplementary information (ESI) available: Crystallographic data of 11b, 12b, 14c, and 15a in cif-format. CCDC 1027080 (11b), 1027081 (12b), 1027082 (14c) and 1027083 (15a). For ESI and crystallographic data in CIF or other electronic format see DOI: 10.1039/c4cc08032g
}

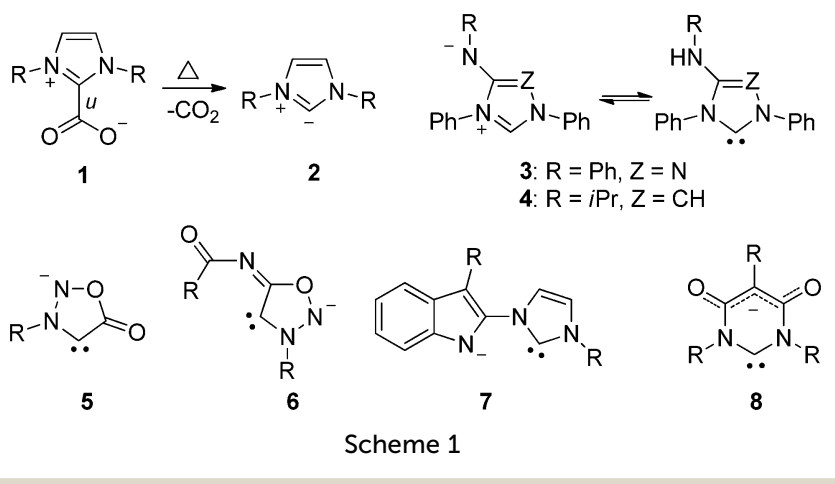

carbenes $5^{10}$ and $6^{11}$ are deprotonated sydnones and sydnonimines, respectively, whereas the carbene 7 was generated from an ylide. ${ }^{12}$ By contrast, carbene $\mathbf{8}^{13}$ is a deprotonated crossconjugated mesomeric betaine (CCMB).

In continuation of our research interests (polycations, ${ }^{14}$ mesomeric betaines, ${ }^{5,6,12}$ synthesis and catalysis with $\mathrm{NHCs}^{15}$ ) we report here on the first hetarenium-phenolates (1,2,4-triazoliumphenolates) which are in equilibrium with their tautomeric carbenes. They form the first representatives of a new ring system upon treatment with boranes.

We started the preparation of the title compounds from 2-aminophenol 9a and its 4-methyl derivate $\mathbf{9 b}$ which induced a nucleophilic ring transformation of 3-phenyl-1,3,4-oxadiazolium salt 10 to give the salts $\mathbf{1 1 a}, \mathbf{b}$ in reasonable yields, respectively (Scheme 2). The $\mathrm{OH}$ group can be detected between $\delta=11.22$ (11a) and 10.95 ppm (11b) in DMSO- $\mathrm{d}_{6}$. Potassium hydroxide in methanol (method A) converted the salts 11a,b at $\mathrm{rt}$ into the 2-(1,2,4-triazolium)phenolates 12a,b the tautomers $\mathbf{A}$ of which are members of the class of conjugated heterocyclic mesomeric betaines (CMB). Upon formation of betaine, the resonance frequency of the $\mathrm{OH}$ groups of 11a,b disappears while the signals of $3-H$ of the triazolium at $\delta=11.27 / 11.25$ ppm broaden considerably. The largest shift differences are observable for the phenolate protons which shift by $\Delta \delta=0.15-0.25 \mathrm{ppm}$ to a higher field. The betaine tautomers 12a,b(A) proved to be stable 

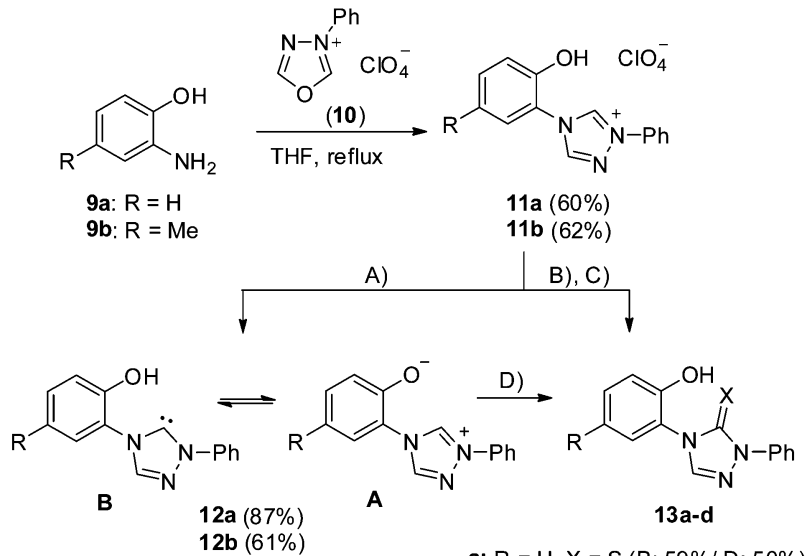

a: $R=H, X=S(B: 59 \% / D: 50 \%)$ b: $\mathrm{R}=\mathrm{H}, \mathrm{X}=\mathrm{Se}(50 \%)$ c: $R=M e, X=S(B: 79 \% / D: 60 \%)$ d: $R=M e, X=\operatorname{Se}(54 \%)$

reaction conditions: A) $\mathrm{KOH}, \mathrm{MeOH}$. B) potassium 2-methylbutan-2-olate, $\mathrm{S}_{8}, \mathrm{THF}, 0^{\circ} \mathrm{C}$, $30 \mathrm{~min}$, then $100^{\circ} \mathrm{C}, 3 \mathrm{~h}$. C) potassium 2-methylbutan-2-olate, Se, THF, $0{ }^{\circ} \mathrm{C}, 30 \mathrm{~min}$, then $100{ }^{\circ} \mathrm{C}, 3 \mathrm{~h}$. D) $\mathrm{S}_{8}$, toluene, reflux, $8 \mathrm{~h}[\mathbf{1 3 a}, \mathbf{1 3 c}]$

Scheme 2

in polar protic solvents such as methanol $\left(E_{\mathrm{T}}^{\mathrm{N}}=0.762\right)$. In aprotic, less polar solvents such as DMSO $\left(E_{\mathrm{T}}^{\mathrm{N}}=0.444\right)$ or THF $\left(E_{\mathrm{T}}^{\mathrm{N}}=0.207\right)$, however, decomposition occurs. The carbene tautomers $\mathbf{1 2 a}, \mathbf{b}(\mathbf{B})$ can be trapped as triazolethiones 13a,c by reaction with sulfur in toluene in $50 \%$ and $60 \%$ yield, respectively (method $\mathrm{D}$ ). The carbene tautomers were also trapped starting from the salts 11a,b in a onestep reaction (methods $\mathrm{B}$ and $\mathrm{C}$ ): deprotonation of $\mathbf{1 1 a}, \mathbf{b}$ with potassium 2-methylbutan-2-olate in THF in the presence of sulfur and selenium, respectively, gave the triazolethiones 13a,c and triazoleselenones $\mathbf{1 3 b} \mathbf{d}$ in acceptable to good yields.

Suitable single crystals of the salt $\mathbf{1 1 b}$ were obtained by slow evaporation of a concentrated solution in ethanol (Fig. 1). The phenol substituent is twisted by $56.24(19)^{\circ}$ (C5-N4-C6-C7) from the plane of the triazolium ring, whereas the phenyl ring and the triazolium ring form an almost planar system in the crystal (see ESI $\dagger$ ).

Suitable single crystals of the corresponding betaine $\mathbf{1 2 b}$ were obtained by slow evaporation of a concentrated solution in EtOHEtOAc. The betaine, which adopts tautomer $\mathbf{1 2 b}(\mathbf{A})$ in the crystal, is stabilized by water of crystallization (Fig. 2). One hydrogen bond is formed from $3-H_{\text {triazole }}(\mathrm{CH}-5$, crystallographic numbering) to

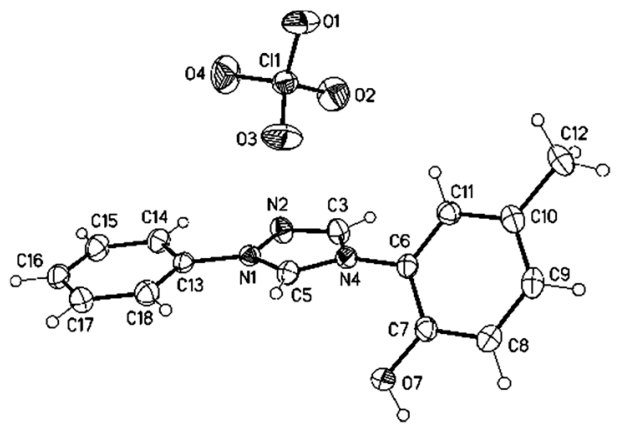

Fig. 1 Molecular drawing of triazolium salt 11b (displacement parameters are drawn at the $50 \%$ probability level).

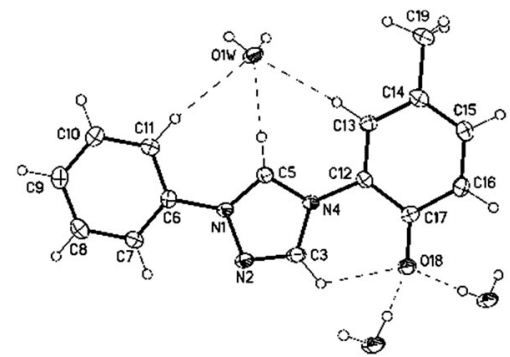

Fig. 2 Molecular drawing of triazolium betaine $12 \mathrm{~b}(\mathrm{~A})$ showing the hydrogen bond pattern (displacement parameters are drawn at the 50\% probability level).

the oxygen atom of water $\left(\mathrm{H} \cdots \mathrm{O} / \mathrm{O}-\mathrm{H} \cdots \mathrm{O}: 203 \mathrm{pm} / 172^{\circ}\right)$, another from the phenolate oxygen atom (O18) to the hydrogen atoms of two water molecules $\left(\mathrm{H} \cdots \mathrm{O} / \mathrm{O}-\mathrm{H} \cdots \mathrm{O}\right.$ : $188(2) \mathrm{pm} / 177(3)^{\circ}$; 192(2) $\left.\mathrm{pm} / 163(3)^{\circ}\right)$. In contrast to the corresponding salt $\mathbf{1 1 b}$, the phenol substituent is twisted only slightly by $-7.4(3)^{\circ}$ (C3-N4-C12-C17) from the plane of the triazolium ring. Upon deprotonation, the $\mathrm{C}-\mathrm{O}$ bond of the phenol shortens by approximately $6 \mathrm{pm}$ (see ESI $\dagger$ ).

Borane adducts of $\mathrm{N}$-heterocyclic carbenes have attracted considerable attention in the last few years. ${ }^{16}$ The betaine-carbene tautomers 12a,b reacted with triphenylborane and tris(pentafluorophenyl)borane in dioxane at rt to form the triazolium phenoxytriphenylborates 14a-d, respectively (Scheme 3). Triethylborane and triphenylborane converted 12a,b at elevated temperatures into first representatives of the new heterocyclic ring system benzo[e]1,2,4triazolo[3,4-c] [1,4,2] oxazaborininium-4-ide 15a-d which are formal trapping products of an anionic N-heterocyclic carbene possessing a phenolate moiety. Correspondingly, the phenylborates $\mathbf{1 5 b} \mathbf{d}$ are also available in excellent yields starting from 14b,d upon heating. The ${ }^{11} \mathrm{~B}$ NMR resonance frequencies of $\mathbf{1 4} \mathbf{b}, \mathbf{d}$ shift from -6.56 and $-6.57 \mathrm{ppm}$, respectively, to -0.08 and -0.80 ppm upon ring closure to $\mathbf{1 5 b}, \mathbf{d}$.

Suitable single crystals of $\mathbf{1 4 c}$ were obtained by slow evaporation of a concentrated solution in DMSO. The bond length between the phenolate oxygen and the boron atom (O19-B20) was determined to be $150.30(19) \mathrm{pm}$. The phenyl rings are twisted by $-120.8(3)^{\circ}$ $(\mathrm{C} 5-\mathrm{N} 1-\mathrm{C} 6-\mathrm{C} 7)$ and $148.59(15)^{\circ}(\mathrm{C} 5-\mathrm{N} 4-\mathrm{C} 12-\mathrm{C} 17)\left[-35.7(2)^{\circ}\right.$ (C5-N4-C12-C13)] from the plane of the triazolium ring (Fig. 3).

Finally, suitable single crystals of the new ring system 15a were obtained by slow evaporation of a concentrated solution in ethanol

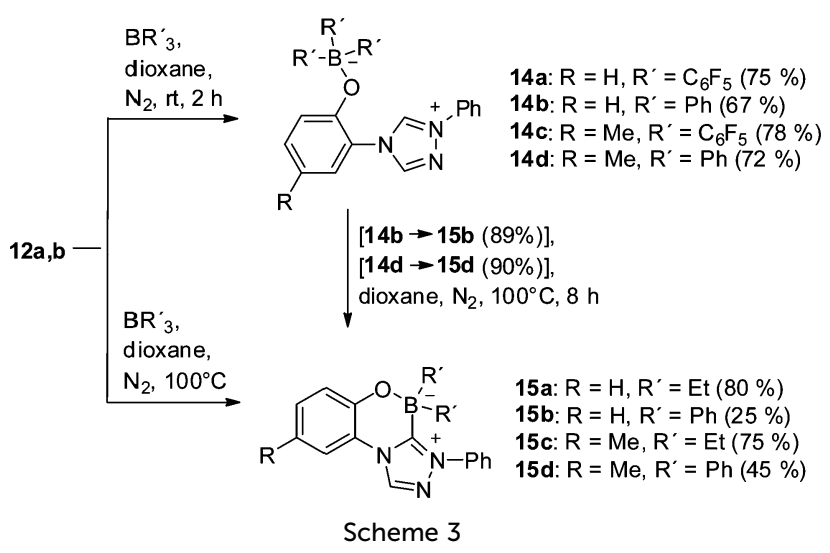




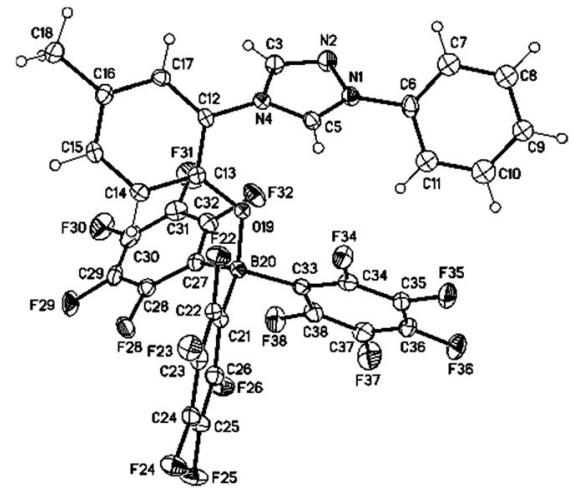

Fig. 3 Molecular drawing of triazolium phenoxytriphenylborate 14c (displacement parameters are drawn at the $50 \%$ probability level).

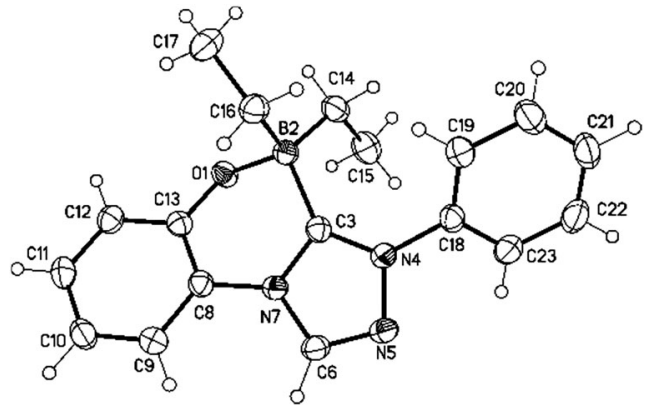

Fig. 4 Molecular drawing of the new heterocyclic ring system 15a (displacement parameters are drawn at the $50 \%$ probability level).

(Fig. 4). In the elemental cell two molecules are connected via one molecule of water which forms hydrogen bonds to the oxygen atoms of the central $[1,4,2]$ oxazaborininium-4-ide cores, respectively $[\mathrm{H} \cdots \mathrm{O} /$ $\mathrm{O}-\mathrm{H} \cdots \mathrm{O}: 188(2) \mathrm{pm} / 178(2)^{\circ}$ and $\left.195(2) \mathrm{pm} / 162(2)^{\circ}\right]$ (cf. Fig. S5, ESI $\dagger$ ). The phenyl rings are twisted by $46.13(18)^{\circ}$ (N5-N4-C18-C23) $-42.7(2)^{\circ}$ (N105-N104-C118-C123) from the plane of the triazolium ring. The oxazaborininium ring is twisted. Thus dihedral angles of $-28.57(16)^{\circ}$ $\left[24.48(17)^{\circ}\right](\mathrm{O} 1-\mathrm{B} 2-\mathrm{C} 3-\mathrm{N} 7)$ and $46.77(15)^{\circ}\left[-46.84(16)^{\circ}\right](\mathrm{C} 13-\mathrm{O} 1-\mathrm{B} 2-$ C3) were measured. The bond lengths $\mathrm{O}_{\text {phenolate }}-\mathrm{B}$ and $\mathrm{C}_{\text {carbene }}-\mathrm{B}$ were determined to be 154.26(17) pm [154.27(19) pm] and 163.9(2) pm [164.2(2) pm], respectively, whereas the bonds connecting the boron atom with the two remaining ethyl groups are shorter (160.6(2) and $162.7(2) \mathrm{pm}$ [160.3(2) pm and 161.8(2) pm)]. In imidazodiazaboroloindoles, trapping products of anionic imidazole-2-ylidenes, the ${ }^{B}-\mathrm{C}_{\text {carbene }}$ bond is longer [165.2(2) pm] than in 15a. ${ }^{17}$ The angle $\mathrm{N}-\mathrm{C}_{\text {carbene }}{ }^{-\mathrm{N}}$ in 15a (N4-C3-N7) was determined to be $103.40(12)^{\circ}$. In the $\mathrm{BH}_{3}$ adduct of 2-phenyl-pyrrolo[2,1-c]-[1,2,4]triazol-3-ylidene the bond length $\mathrm{C}_{\text {carbene }}-\mathrm{B}$ is 161.1(3) pm, the angle $\mathrm{N}-\mathrm{C}_{\text {carbene }}-\mathrm{N}$ is $102.0(2)^{\circ}$ and the $\mathrm{N}-\mathrm{C}_{\text {carbene }}$ bond lengths $136.3(3) \mathrm{pm}$ and 137.0(3) pm, respectively. ${ }^{18}$ Borane adducts of 1,2,4-triazolium-3ylidenes are quite rare. One literature-known example is the trapping reaction of 2,4,5-triphenyl-[1,2,4]triazol-3-ylidenes with $\mathrm{BH}_{3} \cdot \mathrm{THF}^{19}$

In summary, triazolium-phenolates represent an additional class of mesomeric betaines which are in equilibrium with their $\mathrm{N}$-heterocyclic carbenes. This equilibrium gives the access to new borane-containing heterocyclic ring systems which are formed upon trapping with boranes.

\section{Notes and references}

1 C. A. Ramsden, Tetrahedron, 2013, 69, 4146; C. A. Ramsden and W. P. Oziminski, Tetrahedron, 2014, 70, 7158; W. D. Ollis, S. P. Stanforth and C. A. Ramsden, Tetrahedron, 1985, 41, 2239.

2 A. Schmidt, S. Wiechmann and T. Freese, ARKIVOC, 2013, i, 424; A. Schmidt and Z. Guan, Synthesis, 2012, 3251; A. Schmidt and A. Dreger, Curr. Org. Chem., 2011, 15, 2897; A. Schmidt and A. Dreger, Curr. Org. Chem., 2011, 15, 1423; A. Schmidt, A. Beutler and B. Snovydovych, Eur. J. Org. Chem., 2008, 4073.

3 PCCMB are trapping products of $n$ NHCs with heterocumulenes: L. Delaude, Eur. J. Inorg. Chem., 2009, 1681.

4 M. Fèvre, J. Pinaud, A. Leteneur, Y. Gnanou, J. Vignolle, D. Taton, K. Miqueu and J.-M. Sotiropoulos, J. Am. Chem. Soc., 2012, 134, 6776; E. L. Kolychev, T. Bannenberg, M. Freytag, C. G. Daniliuc, P. G. Jones and M. Tamm, Chem. - Eur. J., 2012, 18, 16938; X. Sauvage, G. Zaragoza, A. Demonceau and L. Delaude, Adv. Synth. Catal., 2010, 352, 1934; J. Li, J. Peng, G. Zhang, Y. Bai, G. Lai and X. Li, New J. Chem., 2010, 34, 1330; T. Le Gall, S. Baltatu and S. K. Collins, Synthesis, 2011, 3687; T. K. Olszewski and D. E. Jaskólska, Heteroat. Chem., 2012, 23, 605; M. Albrecht, P. Maji, C. Häusl, A. Monney and H. Müller-Bunz, Inorg. Chim. Acta, 2012, 380, 90; P. Bissinger, H. Braunschweig, T. Kupfer and K. Radacki, Organometallics, 2010, 29, 3987; L. Tommasi and F. Sorrentino, Tetrahedron Lett., 2009, 50, 104; A. Schmidt, A. Beutler, M. Albrecht and F. J. Ramírez, Org. Biomol. Chem., 2008, 6, 287.

5 A. Schmidt, N. Münster and A. Dreger, Angew. Chem., Int. Ed., 2010, 49, 2790; A. Dreger, R. Cisneros Camuña, N. Münster, T. A. Rokob, I. Pápai and A. Schmidt, Eur. J. Org. Chem., 2010, 4296; A. Schmidt and T. Habeck, Lett. Org. Chem., 2005, 2, 37.

6 Z. Guan, M. Gjikaj and A. Schmidt, Heterocycles, 2014, 10, 2356; Z. Guan, S. Wiechmann, M. Drafz, E. Hübner and A. Schmidt, Org. Biomol. Chem., 2013, 11, 3558; A. Schmidt, L. Merkel and W. Eisfeld, Eur. J. Org. Chem., 2005, 2124.

7 K. W. Ratts, R. K. Howe and W. G. Phillips, J. Am. Chem. Soc., 1969, 91, 6115; H. Quast and E. Schmitt, Liebigs Ann. Chem., 1970, 732, 43; A. R. Katritzky and H. M. Faid-Allah, Synthesis, 1983, 149.

8 C. Färber, M. Leibold, C. Bruhn, M. Maurer and U. Siemeling, Chem. Commun., 2012, 48, 227.

9 V. César, J.-C. Tourneux, N. Vujkovic, R. Brousses, N. Lugan and G. Lavigne, Chem. Commun., 2012, 48, 2349; A. A. Danopoulos, K. Yu. Monakhov and P. Braunstein, Chem. - Eur. J., 2013, 19, 450. Related systems have been described as well: L. Benhamou, N. Vujkovic, V. César, H. Gornitzka, N. Lugan and G. Lavigne, Organometallics, 2010, 29, 2616; L. Benhamou, V. César, H. Gornitzka, N. Lugan and G. Lavigne, Chem. Commun., 2009, 4720; A. T. Biju, K. Hirano, R. Fröhlich and F. Glorius, Chem. - Asian J., 2009, 4, 1786.

10 S. Wiechmann, T. Freese, M. H. H. Drafz, E. G. Hübner, J. C. Namyslo, M. Nieger and A. Schmidt, Chem. Commun., 2014, 50, 11822.

11 V. N. Kalinin, S. N. Lebedev, I. A. Cherepanov, I. A. Godovikov, K. A. Lyssenko and E. Hey-Hawkins, Polyhedron, 2009, 28, 2411; S.-T. Lin, H.-S. Cheo, L.-S. Liu and J.-C. Wang, Organometallics, 1997, 16, 1803.

12 N. Pidlypnyi, S. Wolf, M. Liu, K. Rissanen, M. Nieger and A. Schmidt, Tetrahedron, 2014, 70, 8672; N. Pidlypnyi, F. Uhrner, M. Nieger, M. H. H. Drafz, E. G. Hübner, J. C. Namyslo and A. Schmidt, Eur. J. Org. Chem., 2013, 7739. An $N$-(fluoren-9-yl)imidazol-2-ylidene was also described: L. Benhamou, S. Bastin, N. Lugan, G. Lavigne and V. César, Dalton Trans., 2014, 43, 4474.

13 V. César, S. Labat, K. Miqueu, J.-M. Sotiropoulos, R. Brousses, N. Lugan and G. Lavigne, Chem. - Eur. J., 2013, 19, 17133; V. César, N. Lugan and G. Lavigne, J. Am. Chem. Soc., 2008, 130, 11286.

14 A. Schmidt and T. Mordhorst, Synthesis, 2005, 781; A. Schmidt, T. Mordhorst and T. Habeck, Org. Lett., 2002, 4, 1375.

15 A. Schmidt and A. Rahimi, Chem. Commun., 2010, 46, 2995; A. Rahimi, J. C. Namyslo, M. Drafz, J. Halm, E. Hübner, M. Nieger, N. Rautzenberg and A. Schmidt, J. Org. Chem., 2011, 76, 7316.

16 D. P. Curran, A. Solovyev, M. M. Brahmi, L. Fensterbank, M. Malacria and E. Lacôte, Angew. Chem., Int. Ed., 2011, 50, 10294.

17 N. Pidlypnyi, J. C. Namyslo, M. H. H. Drafz, M. Nieger and A. Schmidt, J. Org. Chem., 2013, 78, 1070.

18 S.-H. Ueng, M. M. Brahmi, É. Derat, L. Fensterbank, E. Lacôte, M. Malacria and D. P. Curran, J. Am. Chem. Soc., 2008, 130, 10082.

19 D. Enders, K. Breuer, J. Runsink and J. H. Teles, Liebigs Ann., 1996, 2019. 